\title{
MULHER CHEFE DE FAMÍLIA
}

\author{
Maria Tereza Maldonado
}

Segundo os dados do Censo de 2000 do IBGE, 25\% das familias brasileiras são chefiadas por mulheres. A maior proporção é de mulheres com até quatro anos de escolaridade; o rendimento médio varia entre $R \$ 270,00$ e R\$ 590,00 mensais; do total das familias chefiadas por mulheres, 91\% vivem em áreas urbanas.

A cada ano, aumenta a proporção de mulheres chefiando famílias e isso acontece em um grande número de países. Este fenômeno, em parte, deriva-se da escolha de não manterem relacionamentos insatisfatórios, mesmo que isso implique assumir o ônus total ou parcial do sustento; por outro lado, reflete a falta de compromisso comum entre os homens, que confundem o término do casamento com o término da responsabilidade parental de presença e de sustento financeiro para os filhos.

0 que predomina na vida das mulheres que chefiam famílias é a sobrecarga derivada do acúmulo de funções. Ela é a provedora e a cuidadora principal ou exclusiva. Com aumento do estresse, crescem a irritabilidade, a impaciência e a intolerância: em estatísticas de instituições que trabalham com o problema da violência doméstica, as

\footnotetext{
${ }^{\prime}$ Mestre em Psicologia pela PUC-RJ, membro da American Family Therapy Academy e autora de vários livros, entre os quais "Recursos de relacionamento para profissionais de saúde"(ed. REA). Seu site é: www.mtmaldonado.com.br
} 
mães são as principais agressoras. A solidão, a falta de uma rede de apoio eficaz, são fatores que têm um peso significativo.

0 fenômeno do aumento do número de mulheres chefiando famílias aponta também para a questão da "feminização da pobreza": as empregadas domésticas ocupam a maior fatia do mercado de trabalho feminino no Brasil. Nas camadas populares, encontram-se boa parte dos casos de mulheres que têm filhos com diferentes companheiros, os quais não contribuem para o sustento dos mesmos, reforçando a cultura da falta de responsabilidade do homem pela paternidade e a idéia de que "os filhos são da mãe". Como diz um ditado africano: "os homens vão, os filhos ficam".

Por outro lado, muitos homens se queixam de que as mulheres se apossam dos filhos, não compartilhando com eles a função parental, especialmente após a separação: é a síndrome da alienação parental. Isto tem reflexos no judiciário, onde ainda se encontra, em alguns setores, muita resistência ao estabelecimento da guarda compartilhada. A falta de infra-estrutura de apoio e a rede institucional deficiente (creches, escolas em horário integral, onde as crianças possam fazer atividades complementares), contribuem para as dificuldades de criar os filhos.

No livro "A reengenharia do tempo", Rosiska Darcy de Oliveira fala da necessidade de flexibilizar o tempo de trabalho, a partir de outras formas alternativas, já vigentes em alguns países. É preciso aumentar o reconhecimento da importância da vida privada, em contraposição ao mundo do trabalho; é preciso que as empresas se preocupem mais com a qualidade de vida de seus empregados e seus familiares, para que se cuide melhor do capital humano. Essa nova postura significa reconhecer que o trabalho não é a única riqueza da sociedade, mas que cuidar de outros, sejam crianças ou idosos, também é. Na proposta da reengenharia do tempo, encontra-se a necessidade de mudar o mundo do trabalho e das relações entre homens e mulheres, para dar conta das mudanças de organização familiar, inclusive desse aumento crescente de mulheres 
que chefiam famílias. E nisso estão incluidas as mulheres aposentadas que, com sua renda, contribuem significativamente para o sustento de filhos e netos, além de ajudar a cuidar deles para que as mães trabalhem.

Portanto, dentre os vários caminhos possiveis, destacam-se: procurar ampliar as bases de apoio, que podem se referir à possibilidade de compartilhar a criação dos filhos com outros membros da família extensa, contar com o apoio de amigas em situação semelhante, e buscar recursos institucionais disponiveis; em âmbito coletivo, como parte da formação de uma nova consciência acerca da vida e da importância dos tempos de trabalho e de convivio familiar e social, ver a possibilidade de negociar acordos de trabalho mais flexíveis e formular acordos de responsabilidade compartilhada entre homens e mulheres, tendo em vista a produtividade no trabalho e o maior bem-estar para trabalhadores e seus familiares. 